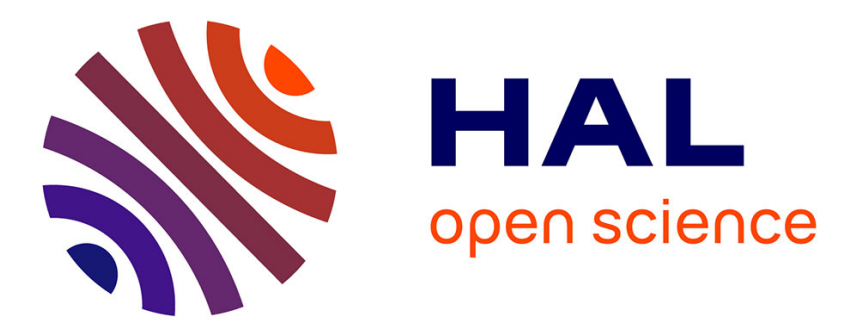

\title{
Decreased antibiotic susceptibility of Enterobacteriaceae causing community-acquired urinary tract infections in French Amazonia
}

\author{
C. Baizet, S. Ouar-Epelboin, G. Walter, E. Mosnier, B. Moreau, Félix \\ Djossou, Loïc Epelboin
}

\section{To cite this version:}

C. Baizet, S. Ouar-Epelboin, G. Walter, E. Mosnier, B. Moreau, et al.. Decreased antibiotic susceptibility of Enterobacteriaceae causing community-acquired urinary tract infections in French Amazonia. Médecine et Maladies Infectieuses, 2019, 49 (1), pp.63-68. 10.1016/j.medmal.2018.09.009 . inserm03066210

\section{HAL Id: inserm-03066210 https://www.hal.inserm.fr/inserm-03066210}

Submitted on 22 Oct 2021

HAL is a multi-disciplinary open access archive for the deposit and dissemination of scientific research documents, whether they are published or not. The documents may come from teaching and research institutions in France or abroad, or from public or private research centers.
L'archive ouverte pluridisciplinaire HAL, est destinée au dépôt et à la diffusion de documents scientifiques de niveau recherche, publiés ou non, émanant des établissements d'enseignement et de recherche français ou étrangers, des laboratoires publics ou privés.

\section{(ㅇ)(1) $\$$}

Distributed under a Creative Commons Attribution - NonCommerciall 4.0 International 


\title{
Diminution de la sensibilité aux antibiotiques des entérobactéries responsables d'infections urinaires communautaires en Amazonie française
}

\section{Decreased antibiotic susceptibility of Enterobacteriaceae causing community-acquired urinary tract infections in French Amazonia}

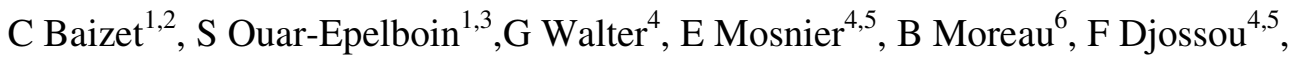 \\ LEpelboin $^{4,5}$
}

1. Service d'Accueil des Urgences / SAMU, Centre hospitalier Andrée Rosemon, 97300 Cayenne, Guyane française

2. Département Universitaire de Médecine Générale, Faculté de Médecine Hyacinthe Bastaraud, Université des Antilles 97157 Pointe-à-Pitre, Guadeloupe

3. Unité de Médecine Judiciaire, Centre hospitalier Andrée Rosemon, 97300 Cayenne, Guyane française

4. Unité des maladies infectieuses et tropicales, Centre hospitalier Andrée Rosemon, 97300 Cayenne, Guyane française

5. Equipe EA 3593, Ecosystèmes amazoniens et pathologie tropicale, Université de la Guyane, Cayenne, Guyane française

6. Laboratoire de microbiologie, Centre hospitalier Andrée Rosemon, 97300 Cayenne, Guyane française

\section{Corresponding author}


Loïc Epelboin, MD, PhD. Unité des Maladies Infectieuses et Tropicales, Centre hospitalier Andrée Rosemon, 97300 Cayenne, Guyane française. Phone: +594 5943950 40;Fax: +594 5943950 41. Email address: epelboincrh@ hotmail.fr.

The study was presented as a poster at the JNI in 2016 (Lille).

\section{Funding: none}

\section{Declaration of interest}

The authors declare no competing interests.

\section{Acknowledgement}

We would like to thank Dr Gerd Donutil for providing data on visits to the emergency department of the hospital of Cayenne and Prof. Magalie Demar and Mathieu Nacher for reviewing the article. We would also like to thank all physicians of the emergency department, the tropical and infectious disease physicians, and those working in other hospital wards who managed the patients of this study. This work has benefited from a grant from the French National Agency for Research (French acronym ANR) (CEBA, ref. ANR-10-LABX25-01).

Mots clés : BLSE ; Guyane française ; infection urinaire

Keywords: ESBL; French Guiana; urinary tract infection 


\section{Résumé}

Objectifs. Les infections urinaires (IU) sont peu étudiées en Amazonie. Notre objectif était de décrire l'épidémiologie des bactéries responsables d'infections urinaires en Guyane.

Patients et méthodes. Étude monocentrique rétrospective réalisée chez les adultes ayant consulté aux Urgences du Centre Hospitalier de Cayenne en 2014 avec un diagnostic d'IU. La répartition des espèces bactériennes et les profils de sensibilité ont été décrits.

Résultats. Deux-cent-quatre-vingt-neuf patients avec IU ont été inclus, dont $82(28,4 \%)$ cystites, $166(57,4 \%)$ pyélonéphrites et $41(14,2 \%)$ IU masculines. E. coli était majoritaire $(74,1 \%)$, et avait une sensibilité diminuée à l'ampicilline, amoxicilline-acide clavulanique, fluoroquinolones, co-trimoxazole et furanes par rapport aux données de France métropolitaine. Les BLSE ont été isolées chez 3,1\% d'E. coli et 31,6\% de K. pneumoniae.

Conclusions. La sensibilité aux antibiotiques dans les IU est moindre que celle rapportée en métropole sans évidence d'une surconsommation antibiotique. 


\section{ABSTRACT}

Objectives. Urinary tract infections (UTIs) have rarely been studied in the Amazon region. We aimed to describe the epidemiology of bacteria causing UTIs in French Guiana.

Patients and methods. We performed a monocenter retrospective study of adults consulting at the emergency department of Cayenne Hospital in 2014 with a diagnosis of UTI. The bacterial species and resistance profile were described.

Results. Two-hundred-and-eighty-nine patients presenting with UTI were included: 82 (28.4\%) presented with cystitis, $166(57.4 \%)$ with pyelonephritis, and 41 (14.2\%) with male UTI. E. coli was predominant $(74.1 \%)$, and had decreased susceptibility to ampicillin, amoxicillin-clavulanic acid, fluoroquinolones, co-trimoxazole, and furans compared with data from metropolitan France. Extended-spectrum beta-lactamases (ESBL) was isolated in 3.1\% of E. coli and $31.6 \%$ of $K$. pneumoniae.

Conclusions. Antibiotic susceptibility in UTI is lower than reported in metropolitan France without evidence for an excessive consumption of antibiotics. 


\section{INTRODUCTION}

In France urinary tract infections (UTIs) are the second site of bacterial infection after bronchopulmonary infections [1]. In French Guiana, one of the French overseas territories of America located on the Guiana Shield, an Amazon region, data on the bacterial ecology of UTIs is almost non-existent. However, extended-spectrum beta-lactamase (ESBL)-producing Enterobacteriaceae have been extensively studied in the isolated Amerindian community of Trois-Sauts, in the extreme south-east of French Guiana [2-4].

We aimed to describe the epidemiology of bacterial species involved in UTIs in French Guiana to gain insight into local specificities to improve professional practices regarding antibiotic prescribing.

\section{METHODS}

\section{Study design and population}

We performed a monocenter observational retrospective study. We included patients aged over 15 years who consulted at the emergency department of Andrée Rosemon Hospital in Cayenne, French Guiana, between January 1 and December 31, 2014.

\section{Case definition and inclusion criteria}

The $10^{\text {th }}$ International Classification of Diseases (ICD-10) was used to identify cases of UTI. The diagnosis was based on a clinical presentation compatible with UTI associated with a positive cytobacteriological examination of urine. The diagnosis of cystitis and pyelonephritis was restricted to female patients. The diagnosis of cystitis was based on the presence of symptoms of lower UTI (dysuria, urgency, frequency, or suprapubic tenderness). The 
diagnosis of acute pyelonephritis was considered in the presence of fever and/or back pain associated with a cytobacteriological examination of urine with leukocyte count $>10^{4} / \mathrm{ml}$ and bacteriuria $>10^{3} \mathrm{CFU} / \mathrm{ml}$ for $E$. coli and $>10^{4} \mathrm{CFU} / \mathrm{ml}$ for other Enterobacteriaceae [1]. The diagnosis of male UTI was based on the association of urinary signs (pollakiuria, dysuria, urinary burns) to which could be added pelvic pain (spontaneous or caused by rectal examination), acute retention of urine, and fever, associated with a positive cytobacteriological examination of urine with a leukocyte count $>10^{4} / \mathrm{ml}$ and a bacteriuria threshold of $10^{3} \mathrm{CFU} / \mathrm{ml}$.

Patients with a negative urine culture were also included in the study if the diagnosis had been made by a specialist during the post-emergency consultation or hospitalization despite a negative cytobacteriological examination of urine, particularly in case of antibiotic treatment prior to microbiological sampling and/or positive blood culture with compatible clinical signs and bacteria.

\section{Microbiological methodology}

Bacterial inoculation was performed on Uriselect ${ }^{\circledR}$ media (Biorad, Marnes-la-Coquette, France) at $35-37^{\circ} \mathrm{C}$ for $18-24$ hours and in an aerobic medium. The bacterial identification was based on conventional biochemical techniques with manual methods by gallery API 20E and API 20 NE for Enterobacteriaceae and gallery API Staph for staphylococci (BioMérieux, Marcy l'Étoile, France) and methods automated by VITEK2 ${ }^{\circledR}$ (BioMérieux, Marcy

l'Étoile, France).

The antimicrobial susceptibility tests were performed by diffusion method in Mueller-Hinton medium (BioMérieux, Marcy l'Étoile, France). The susceptibility of antibiotics was estimated as per the 2013 guidelines of the Antibiogram Committee of the French Society for Microbiology (French acronym CA-SFM) [5]. The identification of ESBL-producing 
Enterobacteriaceae was performed on an ESBL medium (BioMérieux, Marcy l'Étoile, France), and was then confirmed by disc diffusion method to detect synergy [6].

\section{Data collection and analysis}

Data was collected from the computerized records of patients $\left(\mathrm{DMU}^{\circledR}\right.$ and CORA $\left.{ }^{\circledR}\right)$ and biological results (AGFA SRI ${ }^{\circledR}$ ) and were then anonymized. They included demographic, clinical, and microbiological data with results from urine and blood cultures and bacterial identification data, susceptibility testing, and production of ESBL.

\section{Ethical consideration}

The retrospective analysis of medical records in a single-center study is authorized by the French Data Protection Authority (French acronym CNIL) for the evaluation of professional practices (declaration of the database no. 2145898).

\section{RESULTS}

In 2014 a total of 47,251 visits to the emergency department of the Hospital of Cayenne were recorded, including 34,000 for patients aged over 15 years (Figure 1). After deletion of duplicates and exclusion criteria, 289 patients presenting with confirmed UTI were included: $82(28.4 \%)$ had cystitis, $166(57.4 \%)$ pyelonephritis, and $41(14.2 \%)$ male UTI. The sex ratio was 0.17 ( 1 man for 6 women). The mean age was $39.0 \pm 19.6$ years (men: $57.4 \pm 20.0$; $\begin{array}{lllll}\text { women: } & 36.5 & \pm & 18.9 & \text { years; }\end{array}$ A total of $261(90.7 \%)$ urine cultures performed in the 289 patients presenting with UTI resulted in bacterial identification (Table I). The distribution of bacterial species showed a strong predominance of Escherichia coli $(74.1 \%)$, followed by Klebsiella pneumoniae (7.3\%) 
and coagulase-negative staphylococci (CNS) (6.2\%) including Staphylococcus saprophyticus, S. warneri, and S. hominis. The most common bacteria observed in women $(\mathrm{N}=224)$ were $E$. coli $(74.3 \%)$, K. pneumoniae (6.7\%), and CNS (7.2\%). The most common bacteria observed in men $(\mathrm{N}=37)$ were E. coli $(73 \%)$ and $K$. pneumoniae $(10.8 \%)$. E. coli was predominant, especially in pyelonephritis and male UTIs (85.9\% and $73.0 \%$, respectively). E. coli accounted for only $54.9 \%$ of the bacteria responsible for cystitis, followed by CNS (14.6\%; mainly $S$. saprophyticus).

A total of $253(97.7 \%)$ antimicrobial susceptibility tests were performed on the 259 isolated microorganisms; 233 were performed on Enterobacteriaceae strains (Table II). Overall, 32.6\% of the strains were susceptible to ampicillin, $95.1 \%$ to cefotaxime, $100 \%$ to imipenem, $62.4 \%$ to co-trimoxazole, $99.1 \%$ to amikacin, $94.3 \%$ to gentamicin, and $81.6 \%$ to nalidixic acid. $K$. pneumoniae showed a more resistant profile than E. coli. Of the 233 Enterobacteriaceae identified, $12(5.1 \%)$ were ESBL-producing strains (Table II). The proportion of ESBLproducing $K$. pneumoniae strains (6/19 or $31.6 \%)$ was higher than that of ESBL-producing $E$. coli strains $(6 / 192$ or $3.1 \%)(P<0.01)$.

\section{DISCUSSION}

To our knowledge no study has been performed on UTIs in neighboring countries of French Guiana such as Guyana and Suriname. Although many articles on that subject are available in the Brazilian literature, no study has to our knowledge been performed in the Amazonian states near French Guiana [7-11].

The most common bacteria observed in our study were E. coli $(74.3 \%)$, K. pneumoniae (7.3\%), CNS (6.1\%), and Proteus mirabilis (4.2\%). These findings were similar to those 
observed in the French literature [12-14]. In contrast, staphylococci were overrepresented in the bacterial ecology of cystitis (14.6\%), including S. saprophyticus (12.2\%) and S. aureus (3.7\%). S. saprophyticus is usually observed in $7 \%$ of lower UTIs in Europe $[1,12,15]$.

The antibiotic susceptibility of $E$. coli was usually lower than that reported in metropolitan France [1]. Susceptibility to ampicillin, amoxicillin-clavulanic acid, trimethoprimsulfamethoxazole, fluoroquinolones, and furans were therefore significantly lower than that reported in metropolitan France (Table II). Susceptibility to cephalosporins and aminoglycosides was similar to that reported in metropolitan France, and no resistance to carbapenems was observed in our study. The authors of a 2017 article on antibiotic consumption in French Guiana reported a significantly different antibiotic consumption in French Guiana compared to that of metropolitan France [16]. Cyclin consumption was for instance higher in French Guiana, amoxicillin - with or without clavulanic acid - and sulfonamide consumption was comparable or higher, while consumptions of third-generation cephalosporins, carbapenems, and fluoroquinolones were lower than in metropolitan France. Discrepancies between the estimate of antibiotic consumption in French Guiana and the lower susceptibility of these strains can therefore be observed. It is unclear whether this greater proportion of antibiotic resistance is part of a broader regional pattern as no data is available in surrounding countries. Of the Enterobacteriaceae observed in our study, 5.1\% were ESBL-producing Enterobacteriaceae, exclusively E. coli and K. pneumoniae (3.1\% and $31.6 \%$, respectively). This prevalence of ESBLs among E. coli is similar to literature data [17-19]. The proportion of ESBL-producing Enterobacteriaceae was therefore 3.3\% and 6.6\% among 51,643 urine specimens positive for E. coli and K. pneumoniae in France [17-19]. In neighboring Brazil, ESBL-producing Enterobacteriaceae accounted for $7.1 \%$ of 324 E. coli strains isolated from patients presenting with lower urinary tract infections in Brasilia and for $3.0 \%$ of 5,722 
Enterobacteriaceae isolated from patients presenting with UTIs in São Paulo [7, 9]. The epidemiological situation of French Guiana in terms of bacterial resistance differed from that of metropolitan France [16]. A lower frequency of resistance for S. aureus, E. coli, and $P$. aeruginosa but a higher frequency for $K$. pneumoniae were indeed reported. The main limitation of the study is its retrospective nature with missing data. No genotypic characterization of ESBL-producing Enterobacteriaceae was performed during the study period.

\section{Conclusion}

To our knowledge this is the first study assessing the susceptibility profile of bacteria responsible for UTI in French Guiana. Few articles have been published on the subject in the Amazon region. In this Amazon and French medical environment, coagulase-negative staphylococci seem to be more common and ESBL production more common for $K$. pneumoniae, but similar to metropolitan France for $E$. coli. The antibiotic susceptibility of $E$. coli in UTIs is lower than that reported in metropolitan France for antibiotics of daily use.

\section{Contribution of authors}

CB, SOE, and LE designed the study protocol and set up the study.

$\mathrm{CB}$ and LE wrote the article.

LE performed the statistical analysis.

BM performed the microbiological analyses and drafted the microbiological method.

GW, EM, and FD reviewed the article. 


\section{Références}

1. Société de Pathologie Infectieuse de Langue Française (SPILF). Diagnostic et antibiothérapie des infections urinaires bactériennes communautaires de l'adulte. Actualisation au 11 décembre 2015 des recommandations initialement mises en ligne en mai 2014. 2015:43p.

2. Woerther PL, Angebault C, Jacquier H, Clermont O, El Mniai A, Moreau B, et al. Characterization of fecal extended-spectrum-beta-lactamase-producing Escherichia coli in a remote community during a long time period. Antimicrob Agents Chemother. 2013;57(10):5060-6.

3. Lescat M, Clermont O, Woerther PL, Glodt J, Dion S, Skurnik D, et al. Commensal Escherichia coli strains in Guiana reveal a high genetic diversity with host-dependant population structure. Environmental microbiology reports. 2013;5(1):49-57.

4. Grenet K, Guillemot D, Jarlier V, Moreau B, Dubourdieu S, Ruimy R, et al. Antibacterial resistance, Wayampis Amerindians, French Guyana. Emerg Infect Dis. 2004;10(6):1150-3.

5. Société Française de Microbiologie (SFM), European Commitee on Antimicrobial Suseptibility testing (EUCAST). Comité de l'antibiogramme de la Société Francaise de Microbiologie - Recommandations 2017. 2017;V.2.0 Mai:129.

6. Jarlier V, Nicolas MH, Fournier G, Philippon A. Extended broad-spectrum betalactamases conferring transferable resistance to newer beta-lactam agents in Enterobacteriaceae: hospital prevalence and susceptibility patterns. Rev Infect Dis. 1988;10(4):867-78.

7. Goncalves LF, de Oliveira Martins-Junior P, de Melo ABF, da Silva R, de Paulo Martins V, Pitondo-Silva A, et al. Multidrug resistance dissemination by extended-spectrum beta-lactamase-producing Escherichia coli causing community-acquired urinary tract infection in the Central-Western Region, Brazil. Journal of global antimicrobial resistance. 2016;6:1-4.

8. Prestes-Carneiro LE, Azevedo AM, Nakashima MA, Xavier JM, Cabral C. Frequency and antimicrobial susceptibility of pathogens at tertiary public hospital, São Paulo, Brazil. Southeast Asian J Trop Med Public Health. 2015;46(2):276-84.

9. Miranda EJ, Oliveira GS, Roque FL, Santos SR, Olmos RD, Lotufo PA. Susceptibility to antibiotics in urinary tract infections in a secondary care setting from 2005-2006 and 20102011, in Sao Paulo, Brazil: data from 11,943 urine cultures. Rev Inst Med Trop Sao Paulo. 2014;56(4):313-24.

10. Abreu AG, Marques SG, Monteiro-Neto V, Goncalves AG. Extended-spectrum betalactamase-producing enterobacteriaceae in community-acquired urinary tract infections in Sao Luis, Brazil. Brazilian journal of microbiology : [publication of the Brazilian Society for Microbiology]. 2013;44(2):469-71.

11. Dias VC, da Silva VL, Firmo Ede O, Bastos LQ, Bastos AN, Bastos RV, et al. Distribution of ESBL-producing enterobacteria associated to community-acquired monomicrobial urinary tract infections and antimicrobial susceptibility trends over a 9-year period. J Chemother. 2012;24(3):178-81.

12. de Mouy D, Fabre R, Cavallo JD, Arzouni JP, Baynat M, Bicart-See A, et al. [Community-acquired urinary tract infections in 15 to 65 years old female patients in France. Susceptibility of E. coli according to history: AFORCOPI-BIO network 2003]. Med Mal Infect. 2007;37(9):594-8.

13. Lobel B, Valot A, Cattoir V, Lemenand O, Gaillot O. [Comparison of antimicrobial susceptibility of 1,217 Escherichia coli isolates from women with hospital and communityacquired urinary tract infections]. Presse Med. 2008;37(5 Pt 1):746-50. 
14. Agence Française de Sécurité Sanitaire des Produits de Santé (AFSSAPS). Recommandations de bonne pratique. Diagnostic et antibiothérapie des infections urinaires bactériennes communautaires de l'adulte. 2008.

15. Kahlmeter G. An international survey of the antimicrobial susceptibility of pathogens from uncomplicated urinary tract infections: the ECO.SENS Project. $J$ Antimicrob Chemother. 2003;51(1):69-76.

16. Centre d'appui pour la prévention des infections associées aux soins (CPIAS) Nouvelle-Aquitaine. Consommation des antibiotiques et des antifongiques, résistances bactériennes - données 2016, région Guyane - version Août 2017. Dernière date d'accès; 2017:[28 p.]. Available from: https://www.cpias-nouvelle-aquitaine.fr/wpcontent/uploads/2015/05/atb-so2016-guyane-aout2017rev.pdf.

17. Martin D, Fougnot S, Grobost F, Thibaut-Jovelin S, Ballereau F, Gueudet T, et al. Prevalence of extended-spectrum beta-lactamase producing Escherichia coli in communityonset urinary tract infections in France in 2013. J Infect. 2016;72(2):201-6.

18. Thibaut S, Caillon J, Marquet A, Grandjean G, Potel G, Ballereau F. Epidemiology of third-generation cephalosporin-resistant community-acquired Enterobacteria isolated from elderly patients. Med Mal Infect. 2014;44(2):57-62.

19. Calbo E, Romani V, Xercavins M, Gomez L, Vidal CG, Quintana S, et al. Risk factors for community-onset urinary tract infections due to Escherichia coli harbouring extendedspectrum beta-lactamases. J Antimicrob Chemother. 2006;57(4):780-3. 
Figure I. Flow chart of the study

Figure I. Diagramme de flux de l'étude

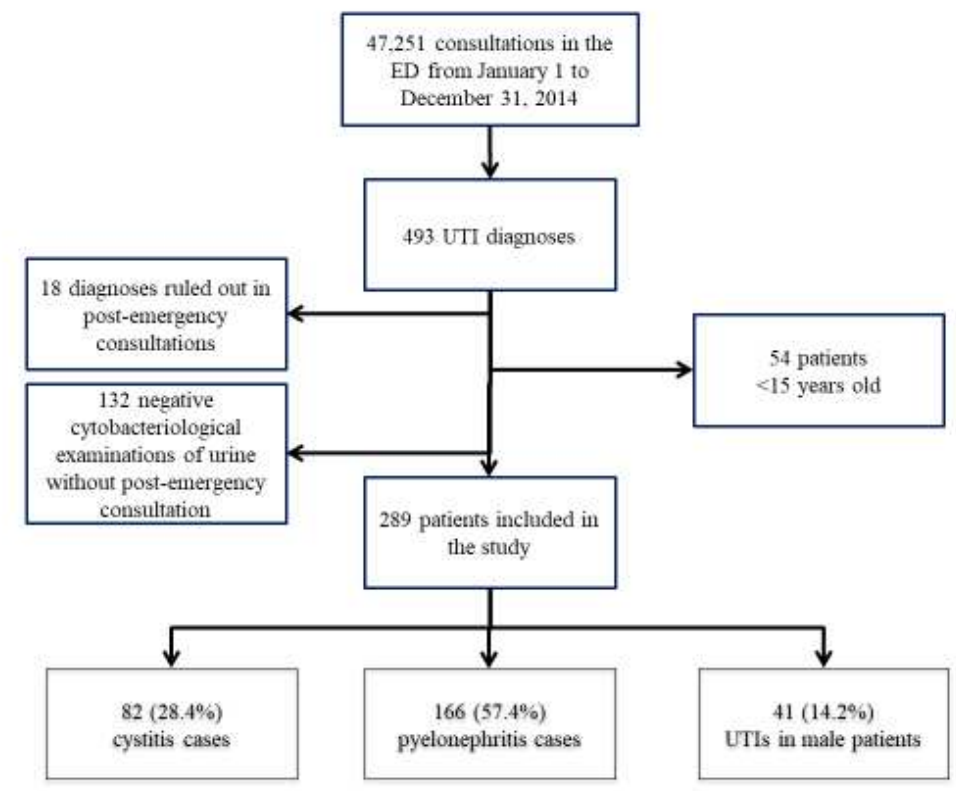

$\mathrm{UTI}=$ urinary tract infection; ED = Emergency department 
Table I. Distribution of bacterial species according to the type of urinary tract infection

Tableau I. Répartition des espèces bactériennes selon le type d'infection urinaire

\begin{tabular}{lllll}
\hline Bacteria & Female & & Male & \\
\hline & Cystitis & Pyelonephrit & Upper & Total \\
& $\mathbf{N}(\%)$ & is & UTI & N (\%) \\
& $\mathbf{N = 8 2}$ & $\mathbf{N}(\%)$ & $\mathbf{N}(\%)$ & $\mathbf{N = 2 6 1}$ \\
& & $\mathbf{N = 1 4 2}$ & $\mathbf{N = 3 7}$ & \\
\hline Escherichia coli & 45 & $122(85.9)$ & $27(73)$ & $194(74.3)$ \\
& $(54.9)$ & & & \\
Klebsiella pneumoniae & $6(7.3)$ & $9(6.3)$ & $4(10.8)$ & $19(7.3)$ \\
Staphylococcus saprophyticus & 10 & $4(2.8)$ & $0(0)$ & $14(5.3)$ \\
& $(12.2)$ & & & \\
Proteus mirabilis & $6(7.3)$ & $2(1.4)$ & $2(5.4)$ & $10(3.8)$ \\
Streptococcus agalactiae & $4(4.9)$ & $2(1.4)$ & $0(0)$ & $6(2.3)$ \\
Enterobacter cloacae & $3(3.7)$ & $1(0.7)$ & $1(2.7)$ & $5(1.9)$ \\
Other Enterobacteriaceae* & $1(1.2)$ & $2(1.4)$ & $1(2.7)$ & $4(1.5)$ \\
Enterobacter aerogenes & $2(2.4)$ & $0(0)$ & $2(5.4)$ & $4(1.5)$ \\
Staphylococcus aureus & $3(3.7)$ & $0(0)$ & $0(0)$ & $3(1.1)$ \\
Other coagulase negative & $2(2.4)$ & $0(0)$ & $0(0)$ & $2(0.8)$ \\
staphylococci* & & & & \\
No bacterium identified & $0 / 82(0)$ & $24 / 166(14.5)$ & $4 / 41(9.8)$ & $28 / 289$ \\
Total & 82 & 166 & 41 & $(9.7)$ \\
\hline
\end{tabular}

UTI = urinary tract infection; ED = Emergency department; Other Enterobacteriaceae: Salmonella sp. $(\mathrm{n}=1)$, Citrobacter koseri $(\mathrm{n}=1)$, Acinetobacter baumannii $(\mathrm{n}=1)$, Pantoea $\mathrm{sp}$. $(\mathrm{n}=1)$; other coagulase negative staphylococci: $S$. warneri $(\mathrm{n}=1)$ et $S$. hominis $(\mathrm{n}=1)$. 
Table II. Susceptibility to various antibiotic classes of ESBL and non-ESBL Enterobacteriaceae and comparison with metropolitan France data according to the SPILF 2015 update.

Tableau II. Sensibilité aux différentes familles d'antibiotiques des entérobactéries BLSE et non BLSE et comparaison aux données de métropole selon la mise au point de la SPILF 2015.

\begin{tabular}{|c|c|c|c|c|c|c|}
\hline & $\begin{array}{l}\text { Total } \\
\text { Enterobacteri } \\
\text { aceae }\end{array}$ & $\begin{array}{l}\text { Non-ESBL- } \\
\text { producing } \\
\text { Enterobacteri } \\
\text { aceae }\end{array}$ & $\begin{array}{l}\text { ESBL- } \\
\text { producing } \\
\text { Enterobacteri } \\
\text { aceae }\end{array}$ & $\begin{array}{l}\text { K. } \\
\text { pneumon } \\
\text { iae }\end{array}$ & $\begin{array}{l}E . \\
\text { coli }\end{array}$ & $\begin{array}{l}\text { Susceptibi } \\
\text { lity to } E \text {. } \\
\text { coli } \\
\text { according } \\
\text { to SPILF }\end{array}$ \\
\hline & $\mathbf{N}(\%)$ & $\mathbf{N}(\%)$ & $\mathbf{N}(\%)$ & $\mathbf{N}(\%)$ & $\begin{array}{l}N \\
(\%)\end{array}$ & $(\%)$ \\
\hline $\begin{array}{l}\text { amoxicilli } \\
\text { n- } \\
\text { clavulani } \\
\text { c acid }\end{array}$ & $126(55.2)$ & $123 / 217(56.7)$ & 3/11 (27.3) & $\begin{array}{l}12 / 18 \\
(66.7)\end{array}$ & $\begin{array}{l}104 / 1 \\
89 \\
(\mathbf{5 5 . 0})\end{array}$ & 67.4-71.1 \\
\hline ampicillin & $74 / 227(32.6)$ & $72 / 216(33.3)$ & 2/11 (18.2) & $\begin{array}{l}1 / 18 \\
(5.6)\end{array}$ & $\begin{array}{l}67 / 18 \\
8 \\
(\mathbf{3 5 . 6})\end{array}$ & $54.8-56.1$ \\
\hline ticarcillin & $89 / 228(39.0)$ & $87 / 218(39.9)$ & $2 / 10(20.0)$ & $\begin{array}{l}1 / 17 \\
(5.9)\end{array}$ & $\begin{array}{l}72 / 18 \\
9 \\
(\mathbf{3 8 . 1})\end{array}$ & - \\
\hline $\begin{array}{l}\text { piperacill } \\
\text { in/ } \\
\text { tazobacta } \\
\text { m }\end{array}$ & $175 / 189(92.6)$ & $170 / 180(94.4)$ & $5 / 9(55.6)$ & $\begin{array}{l}11 / 16 \\
(68.8)\end{array}$ & $\begin{array}{l}147 / 1 \\
56 \\
(\mathbf{9 4 . 2})\end{array}$ & - \\
\hline cefalotin & $136 / 225(60.4)$ & $134 / 214(62.6)$ & 2/11 (18.2) & $\begin{array}{l}13 / 18 \\
(72.2)\end{array}$ & $\begin{array}{l}112 / 1 \\
87 \\
(\mathbf{5 9 . 9})\end{array}$ & - \\
\hline $\begin{array}{l}\text { cefotaxim } \\
\text { e }\end{array}$ & $214 / 225(95.1)$ & $211 / 217(97.2)$ & 3/11 (27.3) & $\begin{array}{l}13 / 18 \\
(72.2)\end{array}$ & $\begin{array}{l}181 / 1 \\
89 \\
(\mathbf{9 5 . 8})\end{array}$ & 96.5 \\
\hline $\begin{array}{l}\text { ceftazidi } \\
\text { me }\end{array}$ & $217 / 229(94.8)$ & $214 / 218(98.2)$ & $3 / 11(27.3)$ & $\begin{array}{l}13 / 18 \\
(72.2)\end{array}$ & $\begin{array}{l}183 / 1 \\
89 \\
(\mathbf{9 6 . 8})\end{array}$ & - \\
\hline cefoxitin & $211 / 217(97.2)$ & $205 / 227(94.5)$ & $6 / 11(54.5)$ & $\begin{array}{l}14 / 18 \\
(77.8)\end{array}$ & $\begin{array}{l}185 / 1 \\
89 \\
(\mathbf{9 7 . 9})\end{array}$ & - \\
\hline imipenem & $227 / 227(100)$ & $216 / 216(100)$ & $11 / 11(100)$ & $\begin{array}{l}18 / 18 \\
(100)\end{array}$ & $\begin{array}{l}189 / 1 \\
89 \\
(\mathbf{1 0 0})\end{array}$ & - \\
\hline $\begin{array}{l}\text { ertapene } \\
\text { m }\end{array}$ & $228 / 228(100)$ & $217 / 217(100)$ & 11/11 (100) & $\begin{array}{l}18 / 18 \\
(100)\end{array}$ & $\begin{array}{l}189 / 1 \\
89 \\
(\mathbf{1 0 0})\end{array}$ & - \\
\hline $\begin{array}{l}\text { tobramyc } \\
\text { in }\end{array}$ & 178/191 (93.2) & $175 / 182(96.2)$ & $3 / 9(33.3)$ & $\begin{array}{l}12 / 16 \\
(75)\end{array}$ & $\begin{array}{l}148 / 1 \\
57\end{array}$ & - \\
\hline
\end{tabular}


(94.3)

\begin{tabular}{|c|c|c|c|c|c|c|}
\hline & & & & & $(94.5)$ & \\
\hline amikacin & $226 / 228(99.1)$ & $217 / 218(99.5)$ & $9 / 10(90)$ & $\begin{array}{l}16 / 17 \\
(94.1)\end{array}$ & $\begin{array}{l}188 / 1 \\
89 \\
(\mathbf{9 9 . 5 )}\end{array}$ & 97 \\
\hline $\begin{array}{l}\text { gentamici } \\
\text { n }\end{array}$ & $216 / 229(94.3)$ & $212 / 218(97.2)$ & 4/11 (36.4) & $\begin{array}{l}13 / 18 \\
(72.2)\end{array}$ & $\begin{array}{l}181 / 1 \\
89 \\
(\mathbf{9 5 . 8})\end{array}$ & - \\
\hline $\begin{array}{l}\text { nalidixic } \\
\text { acid }\end{array}$ & $186 / 228(81.6)$ & $183 / 217(84.3)$ & $3 / 11(27.3)$ & $\begin{array}{l}11 / 18 \\
(61.1)\end{array}$ & $\begin{array}{l}154 / 1 \\
89 \\
(\mathbf{8 1 . 5})\end{array}$ & $77-84$ \\
\hline ofloxacin & $154 / 185(83.2)$ & $152 / 179(86.9)$ & $2 / 8(25.0)$ & $\begin{array}{l}127 / 156 \\
(81.4)\end{array}$ & $\begin{array}{l}11 / 13 \\
(\mathbf{8 4 . 6})\end{array}$ & - \\
\hline $\begin{array}{l}\text { ciproflox } \\
\text { acin }\end{array}$ & $204 / 223(91.5)$ & $200 / 212(94.3)$ & 4/11 (36.4) & $\begin{array}{l}171 / 184 \\
(92.9)\end{array}$ & $\begin{array}{l}12 / 18 \\
(66.7)\end{array}$ & $85-90.4$ \\
\hline $\begin{array}{l}\text { TMP/SM } \\
\mathrm{X}\end{array}$ & $143 / 229(62.4)$ & $141 / 218(64.7)$ & 2/11 (18.2) & $\begin{array}{l}114 / 189 \\
(60.3)\end{array}$ & $\begin{array}{l}11 / 18 \\
(\mathbf{6 1 . 1})\end{array}$ & $76.5-87$ \\
\hline furans & $207 / 1 / 20$ & $197 / 217(90.8)$ & $10 / 11(90.9)$ & $\begin{array}{l}188 / 189 \\
(99.5)\end{array}$ & $\begin{array}{l}13 / 18 \\
(\mathbf{7 2 . 2})\end{array}$ & $98.2-98.7$ \\
\hline
\end{tabular}

ESBL: extended-spectrum beta-lactamase ; TMP/SMX: trimethoprim/sulfamethoxazole 